\section{Cambridge first with local law}

\section{Boston}

SLOWLy but steadily the city of Cambridge, Massachusetts, is moving towards passage of the first local ordinance in the United States governing the care of laboratory animals.

Last week, before a packed crowd of animal advocates and representatives from the research community, Cambridge City Council voted unanimously to write the recommendations of its advisory panel into the form of a local ordinance. That includes the establishment of a city "Commissioner of Laboratory Animals" and is expected to pass the council with little opposition.

The City Council decision to heed the panel's advice has been greeted favourably. Animal rights groups claim the move towards local regulation as a victory, although some advocate even stricter provisions. Most researchers in the city, meanwhile, welcome the new regulations publicly, but privately are relieved that research will not be restricted by more draconian measures.

The council was under a great deal of pressure from animal groups to act on the issue. The three-member panel, which included a local veterinarian and representatives from the scientific community and animal rights groups, gained respect from opposing sides in the debate and was praised by members on both sides for the quality of its work. The panel's recommendations are the culmination of a yearlong investigation of the care of laboratory animals in the city (see Nature 338, 534; 13 April 1989).

The proposal that the city should appoint a Commissioner of Laboratory Animals is the most dramatic of those incorporated in the new ordinance. The commissioner will have authority to "make unannounced visits to inspect animal and research facilities as needed". The commissioner will make at least one annual visit to each research institution in the city, according to the recommendations.

The proposed ordinance will also require all research institutions in the city to conform to federal statutes and regulations concerning the care of laboratory animals. At present, most of the city's laboratories merely conform voluntarily to federal guidelines. The ordinance will also require that each research institution maintains an "autonomous animal care and use committee with the power to disapprove or restrict research" in accordance with federal laws. Each committee will have to include a member who is not affiliated with the research institution.

John Moses, an MIT physician who heads the university's animal care committee, and who represented the scientific community on the advisory panel, calls the proposed ordinance "a necessary step to give the city and the local community the accountability that they need" on the treatment of laboratory animals. He says the panel's recommendations are "very simple", "inexpensive" and "easy to live with", adding that they could help build public trust and stave off more rigid community regulation. "If researchers have to spend a few extra hours a year to achieve greater public confidence", he says, "it's well worth it."

Moses' sentiments were echoed by several other researchers in the area, including James Fox, Head of MIT's Division of Comparative Medicine. Fox says that "the biomedical research community is certainly amenable" to peer review of animal care. "If it makes the Cambridge community more comfortable", he adds, "I think that it is acceptable."

Although the thrust of the new ordinance reflects the panel's recommendations, many key details are still to be decided. Differences remain on the method by which the city commissioner will be selected and on the question of

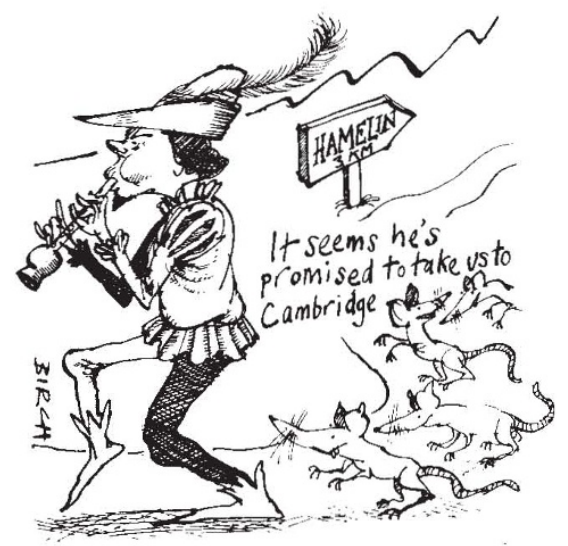

whether animal care committees should be required to include an animal welfare advocate. These details are expected to be decided early this summer when the City Council votes offically on the new regulations.

Cambridge Mayor Al Vellucci, who gave his public endorsement to the panel's recommendations and announced before last week's crowd that he will vote for the ordinance when it is written, likened the current situation to the recombinant DNA debate in Cambridge ten years ago in which he played a key role. Vellucci told the packed meeting that in the former debate, "Nobel laureate scientists told us how damaging our regulations would be to their research; but once we passed it, they acknowledged that they could live with it". So, says Vellucci, will it be with the care of laboratory animals.

Seth Shulman

\section{Just another meeting?}

\section{Montreal}

LAST week's Fifth International Conference on AIDS ended without significant deepening of understanding of the pathogenesis of the disease or progress in developing a vaccine, and with a widespread feeling that for biomedical researchers the annual conference has turned into just another scientific meeting.

Public policy pronouncements and discussions of the sociological and behavioural aspects of the AIDS pandemic were more prominent than presentations of new biomedical research, and the focus was on how society will cope with the epidemic, given that biological science offers no immediate answers.

As at last year's AIDS conference in Stockholm, most of the biomedical presentations were updates of continuing research, with very few significantly new reports. Many epidemiologists seemed to feel that the heady days of rapid strides in knowledge have slowed to a more routine pace.

But many were less stoical, complaining that sessions dealing with similar topics had been scheduled simultaneously, and that the conference's nearly 12,000 participants and wide range of topics made meaningful exchanges between people in the same field impossible.

Robert Gallo, from the US National Cancer Institute, said that "we didn't expect this much diversity", adding that "we can't even find one another to talk."

Controversy surrounded a plenary address from the health commissioner of New York City, Stephen C. Joseph, who said that advances in the treatment of HIV-infected people that prevent their progression to disease may make it necessary to register infected individuals and to trace their sexual partners. But the new US Assistant-Secretary for Health, James O. Mason, said that it is important to "avoid contention" and that, until HIVinfected individuals are "comfortable" with the idea of contact tracing, it is more important to provide anonymous testing to avoid driving people away from diagnosis and treatment.

As the conference closed, there was some talk of dividing next year's AIDS conference - to take place in San Francisco - into separate meetings on biomedical advances and socioeconomic implications so as to make the programme more manageable. The Sixth International Conference on AIDS is expected to draw roughly 18,000 participants. Asked whether many scientists will avoid next year's meeting because the event has grown too big, Gallo hedged with "some will and some won't". 